\title{
EFFECTS OF ASSET STRUCTURE, OPERATING CASH FLOW, AND PROFITABILITY ON DEBT POLICY IN PROPERTY AND REAL ESTATE COMPANIES ON THE INDONESIA STOCK EXCHANGE PERIOD 2013-2017
}

\author{
Meilianta Br Peranginangin ${ }^{1}$, Cathrin Mutiara Saragih ${ }_{5}^{2}$, Hantono $^{3}$, Namira Ufrida Rahmi ${ }^{4}$, \\ Siti Tiffany Guci ${ }^{5}$ \\ ${ }^{12345}$ Accounting Program, Faculty of Economics, University of Prima Indonesia, Jl. Sekip Simp Sikambing, \\ Medan, 20118, Indonesia
}

Corresponding e-mail: meyliantaangin@gmail.com

\begin{abstract}
This study aims to determine the effect of asset structure, operating cash flow, and profitability on debt policy in property and real estate companies in the Indonesia Stock Exchange in 2013-2017. The analytical method used is multiple linear regression, F test and $t$ test. The results of the analysis of this study indicate that the structure of assets, operating cash flows, and profitability have a simultaneous effect on debt policy. Meanwhile the analysis partially shows that the asset structure, operating cash flows, and profitability do not partially affect debt policy.
\end{abstract}

Keywords: the asset structure, operating cash flow, profitability, debt policy

\section{INTRODUCTION}

In running its business, companies need capital. Moreover, property and real estate companies definitely need large capital. Capital can be obtained from inside and outside the company to meet funding needs. Debt policy is one of the decisions that come from outside the company. This debt policy is carried out to increase company funds that will be used to meet the company's operational needs. Debt is an important mechanism to control manager's actions and reduce agency problems in the company. Assets owned by the company will have an influence on the relationship of the company with other parties, because assets are one guarantee that can provide loan funds to companies, so companies with a more flexible asset structure will find it easier to get loans.

Cash flow reports play a very large role, especially for companies and shareholders (investors), as well as for the government and society in general. The function of the cash flow report for the company is to find out about the effectiveness of the policies that have been set by the company in the use or utilization of the cash in a certain time. In addition, cash flow reports can be used by investors and other parties to find out about the company's financial position so that they can determine strategic policies in investment activities in the company. The next one that is thought to influence the company's debt policy is profitability. Profitability is the company's ability to generate profits or benefits for a certain period. Companies that have high profitability mean they will hold back profits, so managers do not need additional external funding sources. Instead, the company will choose additional external funding sources, namely debt in meeting the company's operational costs. This is due to the company holding back some of its profits on retained earnings so that it relies on internal sources and relatively reduces the use of debt. This is in accordance with the Pecking Order Theory which states that companies will prefer to prioritize the use of internal funding sources of the company, and the shortcomings are met using external funding sources.

This study conducts firms in property and real estate companies listed on the Indonesia Stock Exchange. The reason of this study for choosing these companies because the Property and Real Estate companies have bright prospects in the future by taking into 
account the potential for a growing population, more development in the housing sector, apartments, shopping centers, and office buildings that make investors interested in investing their funds so that the prospect of stock trading is expected to continue to increase. The reason the researchers chose the debt policy was because this policy decided by management often caused conflict with shareholders. This study analyzes effects of variables of asset structure, operating cash flow, and profitability. The phenomenon that occurs in Property and Real Estate companies listed on the Indonesia Stock Exchange for the period 2013-2017 is that investors are interested in investing in property and real estate companies because these companies have bright prospects in the future. Based on existing problems then the objectives to be achieved in this study are as follow: (1) to test and analyze the effect of asset structure on debt policy in property and real estate companies listed on the Indonesia Stock Exchange from 2013-2017; (2) to test and analyze the effect of operating cash flows on debt policy in property and real estate companies listed on the Indonesia Stock Exchange from 2013-2017; (3) to test and analyze the effect of profitability on debt policy in property and real estate companies listed on the Indonesia Stock Exchange from 2013-2017; and (4) to test and analyze the simultaneous effects of asset structure, operating cash flow, and profitability on debt policy in property and real estate companies listed on the Indonesia Stock Exchange from 2013-2017.

\section{LITERATURE REVIEWS}

Debt policy. According to Jumingan (2014:25), debt policy is an obligation on other parties to pay a sum of money or deliver goods or services. According to Kasmir (2012:158), the indicators of debt policy are as follows:

$$
\text { DER }=\frac{\text { Total assets }}{\text { Equity }}
$$

Asset structure. Jumingan (2014: 13), asset structure is a property or form of corporate investment. The form can be in the form of assets or wealth or rights to property or services owned by the company concerned. According to Sumarsan (2013: 51), the indicator of asset structure is as follows:

$$
\text { Asset structure }=\frac{\text { Fixed assets }}{\text { Total assets }}
$$

Operating cash flow. According to Dermawan (2013: 8) operating cash flow shows the cash inflows and outflows contained in the income statement and the decline is an increase in the working capital sector (current assets and current liabilities). According to Harmono (2014:85), the indicator of the operating cash flow is as follows:

$$
\text { The Operating Cash Flow }=\text { EBIT }+ \text { Depreciation }- \text { Tax }
$$

Profitability. According to Hery (2017: 192), profitability is a ratio used to measure a company's ability to generate profits from the normal activities of its business. According to Sudana (2012:22), the indicator of profitability is as follows:

$$
\text { ROA }=\frac{\text { Earnings after taxes }}{\text { Total assets }}
$$




\section{RESEARCH METHODS}

\subsection{Data}

The data collection technique carried out in this study was a study of documentation. According to Sugiyono (2011: 240), documentation is data collection carried out by studying documents in the form of writing, pictures or monumental works from someone. For this study, data collection was obtained from the financial statements of property and real estate companies listed on the Indonesia Stock Exchange for the period 2013-2017 which were published on www.idx.co.id. The types and sources of data used in this study are secondary data. Secondary data is processed information data obtained from the financial statements of property and real estate companies listed on the Indonesia Stock Exchange for the period 2013-2017 which are published on www.idx.co.id.

\subsection{Sample}

Sugiyono (2011: 80), population is a region of generalization consisting of objects or subjects that have certain qualities and characteristics set by researchers to be studied and then conclusions drawn. The population used for this study is all property and real estate companies listed on the Indonesia Stock Exchange from 2013-2017 totaling 52 companies. The sampling technique is to use the purposive sampling method. According to Sugiyono (2011: 85), purposive sampling is a technique of determining samples with certain considerations. Table 1 presents the sample of this study with criteria as follow:

1. Property and real estate companies listed on the Indonesia Stock Exchange for the period 2013-2017.

2. Property and real estate companies that publish financial reports on the Indonesia Stock Exchange for the period 2013-2017.

3. Property and real estate companies that earn profits listed on the Indonesia Stock Exchange for the period 2013-2017.

4. Property and real estate companies that have positive cash flows listed on the Indonesia Stock Exchange in the period 2013-2017.

\section{Table 1. Sample}

\begin{tabular}{clc}
\hline No & \multicolumn{1}{c}{ Criteria } & Firms \\
\hline 1 & $\begin{array}{l}\text { Property and real estate companies listed on the Indonesia Stock } \\
\text { Exchange for the period 2013-2017 }\end{array}$ & 48 \\
2 & $\begin{array}{l}\text { Property and real estate companies that publish financial reports on the } \\
\text { Indonesia Stock Exchange for the period 2013-2017 }\end{array}$ \\
3 & $\begin{array}{l}\text { Property and real estate companies that earn profits listed on the } \\
\text { Indonesia Stock Exchange for the period 2013-2017 }\end{array}$ \\
4 & $\begin{array}{l}\text { Property and real estate companies that have positive cash flows listed on } \\
\text { the Indonesia Stock Exchange in the period 2013-2017 }\end{array}$ \\
5 & Total property and real estate companies that meet the sample criteria & 10 \\
\hline & Total observe data of 5 years & $\mathbf{5 0}$ \\
\hline
\end{tabular}

\subsection{Method of analysis}

To find out the effect of independent variables and dependent variables multiple linear regression analysis formula is used to determine the magnitude of the relationship and the effect of independent variables which number 3 (three) or more $\left(\mathrm{X}_{1}, \mathrm{X}_{2}, \mathrm{X}_{3}\right)$ on the dependent variable (Y). With the following formulations:

$$
Y=\alpha+\beta_{1} X_{1}+\beta_{2} X_{2}+\beta_{3} X_{3}+\varepsilon
$$

where $Y$ is Debt Policy, $\alpha$ is constant, $\beta$ is regression coefficient of each independent variables, and $\varepsilon$ is percentage error (0.05). 


\section{RESULTS AND DISCUSSION}

\subsection{Results}

The sample in this study consisted of 10 companies with a research period from 20132017 so that as many as 50 research data were obtained. Table 2 presents the results of data processing for descriptive statistics.

Table 2. Summary of Descriptive Statistics

\begin{tabular}{lccccc}
\hline & N & Minimum & Maximum & \multicolumn{1}{c}{ Mean } & Std. Deviation \\
\hline Asset Structure (AS) & 50 & 0,002 & 0,846 & 0,15632 & 0,224403 \\
Operational Cash (OC) & 50 & 1,9 & 2337,1 & 661,127 & 656,8458 \\
Profitability (Profit) & 50 & 0,008 & 10,513 & 0,30159 & 1,475601 \\
Debt Policy (DP) & 50 & 0,178 & 3,701 & 1,002314 & 0,580759 \\
Valid N (listwise) & 50 & & & & \\
\hline
\end{tabular}

Source: Results of Data Processing

Normality test. The normality test aims to test whether in the regression model, the residual confounding variable has a normal distribution. The results of the normality test can be in the form of a Kolmogorov Smirnov statistical table. In this test, the guidelines used in decision making are: (1) if the significance value is greater than 0.05 then the data is normally distributed; and (2) if the significance value is smaller than 0.05 then the data is not normally distributed. Table 3 presents the summary of the results of the normality test using the Kolmogorov Smirnov.

Table 3. The results of the normality test using the Kolmogorov-Smirnov test

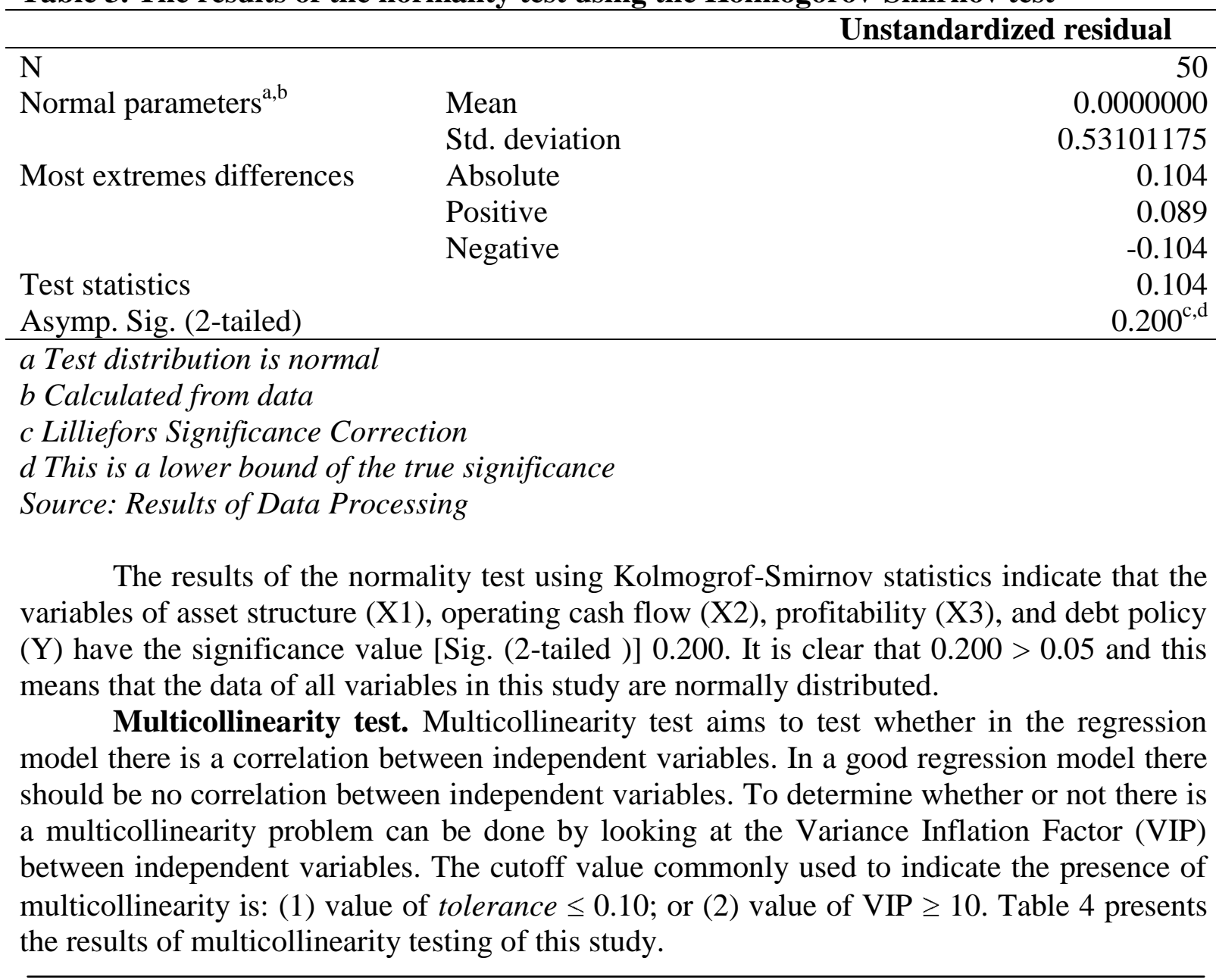


Table 4. Multicollinearity Test

\begin{tabular}{lccc}
\hline & \multirow{2}{c}{ Collinearity statistics } \\
\cline { 2 - 4 } & Variables & Tolerance & VIF \\
\hline AS & 0.880 & 1.136 \\
OC & 0.810 & 1.234 \\
Profit & 0.908 & 1.102 \\
\hline
\end{tabular}

Source: Results of Data Processing

The test results show that the tolerance value of the variables of asset structure (X1), operating cash flow (X2), and profitability (X3) are all greater than 0.10 , and therefore it can be concluded that multicollinearity does not occur. VIF values obtained for asset structure variables (X1), operating cash flow (X2), and profitability (X3) are all smaller than 10 and this indicates that there is no multicollinearity between independent variables.

Autocorrelation test. This study uses the Durbin-Watson test in autocorrelation testing. The Durbin-Watson statistic is used to see whether or not residual data occurs randomly. The Durbin-Watson testing criteria are as follows: (a) if the DW-value $<-2$ means that there is positive autocorrelation; (b) if the DW-value is between - 2 and +2 , there is no autocorrelation; and (c) if the DW-value $>+2$ means that there is negative autocorrelation. Table 5 shows the autocorrelation test results of this study. Based on table 5 above, it can be seen that the $\mathrm{dW}$-value of the Durbin-Watson test is 1.913 which is in the interval between -2 to +2 , which is $-2<1.913<+2$. This shows that in the regression model there is no autocorrelation.

Table 5. A Summary of Results of the Durbin-Watson Autocorrelation Test

\begin{tabular}{ccccc}
\hline $\mathbf{R}$ & $\mathbf{R}$ Square & Adjusted R Square & Std. Error of the Estimate & Durbin-Watson \\
\hline 0.184 & 0.034 & -0.031 & 0.55023 & 1.913 \\
\hline
\end{tabular}

Source: Results of Data Processing

Heteroscedasticity test. Heteroscedasticity test is useful to test whether in the regression model there are differences in the variance of the residuals of one observation with the other observations. The glejser test is used to detect the presence or absence of heteroscedasticity in this study. Table 6 shows that the significance values for the variables of asset structure (X1), operating cash flow (X2), and profitability (X3) are greater than 0.05 because it can be concluded that heteroscedasticity does not occur.

Table 6. Heteroscedasticity Test Results by the Glejser Method

\begin{tabular}{|c|c|c|c|c|c|}
\hline \multirow{2}{*}{ Variables } & \multicolumn{2}{|c|}{$\begin{array}{l}\text { Unstandardized } \\
\text { Coefficients }\end{array}$} & \multirow{2}{*}{$\begin{array}{c}\begin{array}{c}\text { Standardized } \\
\text { Coefficients }\end{array} \\
\text { Beta }\end{array}$} & \multirow[t]{2}{*}{$\mathbf{t}$} & \multirow{2}{*}{ Sig. } \\
\hline & Beta & Std. Error & & & \\
\hline Constant & -0.962 & 0.414 & & -2.326 & 0.024 \\
\hline LnAS & -0.090 & 0.053 & -0.253 & -1.715 & 0.093 \\
\hline LnOC & 0.044 & 0.057 & 0.118 & 0.769 & 0.446 \\
\hline LnProfit & -0.133 & 0.080 & -0.242 & -1.668 & 0.102 \\
\hline
\end{tabular}

Source: Results of Data Processing

Coefficient of determination. The coefficient of determination is intended to find out how much the model's ability to explain the dependent variable. If the coefficient of determination (R2) is greater or closer to 1, it can be said that the ability of the independent variable $(\mathrm{X})$ is large to explain the dependent variable (Y). Table 7 shows the result of determination coefficient for the hypothesis in this study. The results of the determination 
coefficient test yielded the value of adjusted R Square (R2) of the determination coefficient of 0.062 or equal to $6.2 \%$. Thus this means that the independent variables influence the debt policy of $6.2 \%$ and the remaining $93.8 \%$ is influenced by other variables.

Table 7. Coefficient of Determination for the Hypothesis

\begin{tabular}{|c|c|c|c|}
\hline $\mathbf{R}$ & R Square & Adjusted R Square & Std. Error of the Estimate \\
\hline 0.345 & 0.119 & 0.062 & 0.54772 \\
\hline
\end{tabular}

Source: Results of Data Processing

Simultaneous testing of hypotheses (F test). The F test is used to show whether all the independent variables included in the model have a simultaneous influence on the dependent variable. To test this hypothesis, the $\mathrm{F}$ statistic is used with the following decisionmaking criteria: (1) if $\mathrm{F}_{\text {counted }}>\mathrm{F}_{\text {table }}$ or sig. $<0.05$, then $\mathrm{H}_{0}$ is rejected and $\mathrm{H}_{\mathrm{a}}$ is accepted; and (2) if $F_{\text {counted }} \leq F_{\text {table }}$ or sig. $\geq 0.05$, then $H_{a}$ is rejected and $\mathrm{H}_{0}$ is accepted. The hypotheses to be tested in this case are:

$\mathrm{H}_{0}$ : asset structure, operating cash flow, and profitability do not have an effect on debt policy in property and real estate companies listed on the Indonesia Stock Exchange for the period 2013-2017.

$\mathrm{H}_{\mathrm{a}}$ : asset structure, operating cash flow, and profitability have an effect on the debt policy in property and real estate companies listed on the Indonesia Stock Exchange for the period 2013-2017.

Table 8 presents results of the simultaneous testing of this study.

Table 8. Summary of F test Results

\begin{tabular}{lrrrrr}
\hline & Sum of squares & df & Mean square & F & Sig. \\
\hline Regression & 1.864 & 3 & 0.621 & 2.071 & 0.117 \\
Residual & 13.800 & 46 & 0.300 & & \\
Total & 15.664 & 49 & & & \\
\hline
\end{tabular}

Source: Results of Data Processing

From the table above it can be seen that the value of $\mathrm{F}_{\text {counted }}$ is 2.071 and from $\mathrm{F}_{\text {table }}$ is

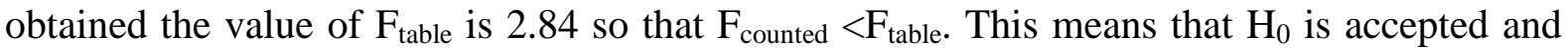
$\mathrm{H}_{\mathrm{a}}$ is rejected. So the conclusion is that the independent variables (asset structure, operating cash flow, and profitability) do not have a significant simultaneous effect on the dependent variable (debt policy) in the Property and Real Estate companies listed on the Indonesia Stock Exchange in the period 2013-2017.

\subsection{Discussions}

The model. Testing the hypothesis used in the study is to use multiple linear regression analysis. The regression models used are as follows:

$$
\text { Ln_DP }=-0.962-0.090 \operatorname{LnAS}+0.044 \text { LnOC }-0.133 \text { LnProfit }
$$

The meanings of the multiple linear regression equation above are:

1. Value of $a$ is $-0,962$, meaning that if the variables of asset structure, operating cash flow, and profitability are considered constant, the debt policy is $-0,962$.

2. The coefficient value of the asset structure is 0.90 . This shows that for every 1 unit increase in asset structure, the debt policy will decrease by 0.90 .

3. The coefficient of the operating cash flow is 0.044 . This shows that for every 1 unit increase in operating cash flow, the debt policy increases by 0.044 .

4. The coefficient of profitability is 0.133 . This shows that for every 1 unit increase in profitability, the debt policy decreases by 0.133 . 
The $t$ test is used to show the extent to which the influence of one independent variable on the dependent variable. This test is done by comparing the significance values with the following conditions:

1. If $-t_{\text {table }} \leq t_{\text {counted }} \leq+t_{\text {table }}$ or Sig. $\geq \alpha=0.05$, then $\mathrm{H}_{\mathrm{a}}$ is rejected and $\mathrm{H}_{0}$ is accepted.

2. If $\mathrm{t}_{\text {counted }}>\mathrm{t}_{\text {table }}$ or $-\mathrm{t}_{\text {counted }} \leq-\mathrm{t}_{\text {table }}$ or Sig. $<\alpha=0.05$, then $\mathrm{H}_{0}$ is rejected and $\mathrm{H}_{\mathrm{a}}$ is accepted.

The hypotheses to be tested in this case are:

$\mathrm{H}_{0} \quad$ : asset structure, operating cash flow, and profitability do not have the partial effect on debt policy in property and real estate companies listed on the Indonesia Stock Exchange for the period 2013-2017.

$\mathrm{H}_{\mathrm{a}} \quad$ : asset structure, operating cash flow, and profitability have the partial effect on the debt policy in property and real estate companies listed on the Indonesia Stock Exchange for the period 2013-2017.

Table 9 presents the summary of the results of the $t$ test of this study.

Table 9. The results summary of the $t$ test

\begin{tabular}{lrrrrr}
\hline \multirow{2}{*}{ Variables } & \multicolumn{2}{c}{$\begin{array}{c}\text { Unstandardized } \\
\text { Coefficients }\end{array}$} & $\begin{array}{c}\text { Standardized } \\
\text { Coefficients }\end{array}$ & \multirow{2}{*}{ t } & \multirow{2}{*}{ Sig. } \\
\cline { 2 - 4 } & \multicolumn{1}{c}{ Beta } & Std. Error & Beta & & \\
\hline Constant & -0.962 & 0.414 & & -2.326 & 0.024 \\
LnAS & -0.090 & 0.053 & -0.253 & -1.715 & 0.093 \\
LnOC & 0.044 & 0.057 & 0.118 & 0.769 & 0.446 \\
LnProfit & -0.133 & 0.080 & -0.242 & -1.668 & 0.102 \\
\hline
\end{tabular}

Source: Results of Data Processing

1. Effect of asset structure on debt policy. The asset structure has a $t_{\text {counted }}$ of $-1.715<2.84$ and a significance value of $0.93>0.05$, then $\mathrm{H}_{0}$ is accepted meaning that the asset structure does not have a significant partial effect on the debt policy in the Property and Real Estate companies listed on the Stock Exchange Indonesia for the period 2013-2017. Based on the results of the partial test it appears that the asset structure does not have a significant effect on the debt policy in the Property and Real Estate companies listed on the Indonesia Stock Exchange in the period 2013-2017. This is not in line with the research hypothesis that the asset structure has a partial effect on the debt policy in the Property and Real Estate companies listed on the Indonesia Stock Exchange in the period 2013-2017. The results of the present study are in line with the results of previous research by Saputrio and Yuliandhari (2015) where they describe that asset structure does not have a positive effect on debt policy. The results of this study are not in line with the opinion of Brigham (2011: 39), which states that companies whose assets are suitable to be used as collateral for loans tend to use debt more. Based on the results of the $t$ test in this study, it was found that the asset structure does not have an effect on debt policy; this is because companies that have a high level of asset structure do not necessarily want to use it to pay off debt.

2. Effect of operating cash flow on debt policy. The operating cash flow has a $t_{\text {counted }}$ of $0.769<2.84$ and a significance value of $0.446>0.05$, then $\mathrm{H}_{0}$ is accepted meaning that the operating cash flow does not have a significant partial effect on the debt policy in the Property and Real Estate companies listed on the Stock Exchange Indonesia for the period 2013-2017. Based on the results of the partial test it appears that operating cash flows have no effect on the debt policy in Property and Real Estate companies listed on the Indonesia Stock Exchange in the period 2013-2017. This is not in line with the research hypothesis that the asset structure has a partial effect on the debt policy in the 
Property and Real Estate companies listed on the Indonesia Stock Exchange in the period 2013-2017. The results of this study are not in line with the results of previous studies by Trikonomika (2013) where it is described that cash flows have a positive effect on debt policy. The results of this study are also not in line with the opinion of Subramayam (2010: 110) which states that cash, not profit, is used to pay debts, change equipment, expand capacity, and pay dividends. Based on the t test it is known that the operating cash flow has no effect on debt policy, this is because companies that have high cash flows do not necessarily want to use it to pay their debts.

3. Effect of profitability on debt policy. Profitability has a $t_{\text {counted }}$ of $-1.668<2.84$ and a significance value of $0.102>0.05$, then $\mathrm{H}_{0}$ is accepted meaning that profitability does not have a significant partial effect on the debt policy in the Property and Real Estate companies listed on the Stock Exchange Indonesia for the period 2013-2017. Based on the results of the partial test it appears that profitability does not affect the debt policy in the Property and Real Estate companies listed on the Indonesia Stock Exchange in the period 2013-2017. This is not in line with the research hypothesis that the asset structure has a partial effect on the debt policy in the Property and Real Estate companies listed on the Indonesia Stock Exchange in the period 2013-2017. The results of the present study are in line with the results of previous studies by Saputrio and Yuliandhari (2015) where they describe that profitability does not have a negative effect on debt policy. The results of this study are not in line with the opinion of Munawir (2014: 34), which states that if a company is unable to obtain large profits, it will eventually experience financial difficulties in paying off its debts. Based on the t test it is known that profitability does not have an effect on debt policy, this is because companies that have a high level of profit do not necessarily want to use it to pay their debts. The results of the Determination Coefficient Test indicate the value of Adjusted R Square is 0.062 , this means that the variation of the dependent variable of debt policy that can be explained by variations in asset structure, operating cash flow, and profitability is only as small as $6.2 \%$.

\section{CONCLUSIONS}

The conclusions that can be drawn as a result of this study are as follow: (1) the asset structure has no effect on the debt policy in Property and Real Estate companies listed on the Indonesia Stock Exchange in the period 2013 - 2017; (2) the operating cash flow has no effect on the debt policy in Property and Real Estate companies listed on the Indonesia Stock Exchange in the period 2013 - 2017; (3) profitability has no effect on the debt policy in Property and Real Estate companies listed on the Indonesia Stock Exchange in the period 2013 - 2017; and (4) ssset structure, operating cash flow and profitability have an effect on the debt policy in Property and Real Estate companies listed on the Indonesia Stock Exchange for the period 2013-2017, with the value of Adjusted R Square of 0.062 which means a variation of asset structure, operating cash flows and profitability is $6.2 \%$.

Suggestions that can be proposed by the author in accordance with the results of this study, among others, are: (1) for University of Prima Indonesia, it is recommended to refer to the results of this study as additional library material that can be used by other students; (2) for Property and Real Estate companies, the formulation of debt policy is an important problem for every company because good and bad debt policies will have a direct effect on the company's financial position. Mistakes in determining debt policy will have a broad impact. Therefore, management should consider the variables that influence debt policy, in this case the asset structure, operating cash flow, and profitability; (3) for investors, can reconsider if they want to make a decision to invest in property and real estate companies because $14.5 \%$ of property and real estate companies ( 7 of 48 companies) suffer losses; and (4) for future researchers, it is recommended to add other variables beyond the variables 
examined by the researcher. Because the results of this study indicate that $6.2 \%$ of the 'debt policy' variable is influenced by other variables e.g. ownership structure, dividend policy, company growth, company size, business risk, and so on.

\section{REFERENCES}

Ikhsan, A. (2008). Akuntansi Lingkungan dan Pengungkapannya. Yogyakarta: Graha Ilmu.

Brealey, R. A., Myers, S. C., \& Marcus, A. J. (2008). Dasar-Dasar Manajemen Keuangan Perusahaan. Jakarta: Erlangga.

Ghozali, I. (2018). Aplikasi analisis multivariete dengan program IBM SPSS 23.

Harahap, S. S. (2013). Analisis Kritis Atas Laporan Keuangan Edisi 11. Jakarta: Rajawali Pers.

Herry.(2017).Analisis Laporan Keuangan.Jakarta:Prima Grafika.

Kasmir .(2012). Analisis Laporan Keuangan.Jakarta : Rajawali Pers.

Kuncoro, M. (2003). Metode riset untuk bisnis dan ekonomi. Jakarta: Erlangga, 52.

Samryn,L.M,(2014). Pengantar Akuntansi.Jakarta:Rajawali Pers.

Sudana, I Made,2011. Manajemen Keuangan Perusahaan.Jakarta:Erlangga.

Sugiri, Slamet dan Bogat Agus Riyono.(2008).Akuntansi Pengantar I. Yogyakarta : STIM

Sugiyono.(2013).Metode Penelitian Kuantitatif,Kualitatif dan R\&D. Bandung:Alfabeta.

Sulitiyowati, Leny.(2010). Panduan Praktis Memahami Analisi Laporan Keuangan . Jakarta: PT Elex Media Komputindo:

Syahyunan.(2013). Manajemen Keuangan. Jakarta : USU Pres.

Wijaya, D. (2017). Manajemen Keuangan Konsep dan Penerapannya. Gramedia Widiasarana.

Yuniarti, A. M. D. (2013). Pengaruh Kepemilikan Manajerial, Dividen, Profitabilitas Dan Struktur Aset Terhadap Kebijakan Hutang. Accounting Analysis Journal, 2(4). 